\title{
ThE IMAge of NATO IN RUSSIAN Television on the 70th AnNiversary of the North Atlantic Pact
}

Agata Krzywdzińska*

Background:The 70th anniversary of the North Atlantic Pact became an impulse to write the article - to discuss the manner in which the topic was presented on Russian public television. Objectives: The aim of the article is to reconstruct NATO's image (the military organization associating twenty-nine countries of Europe and North America) on channel Russia-1 in connection with the seventieth anniversary of the Pact, celebrated on 4 April 2019. Methods: The research materials are analytical programmes and political talk shows broadcast in March and April 2019. A content analysis method was used to examine the programmes. Results: Examination of the programmes showed that Russian public television is a mirror image of the state policy. Conclusions: Russian public state television channel Russia- 1 presents a coherent narrative image of NATO regardless of the

* Agata Krzywdzińska, Ph.D., Jagiellonian University; correspondence address: Department of Modern Russian Culture and Theory of Cultural Systems, Faculty of International and Political Studies Institute of Russia and Eastern Europe, Jagiellonian University, Al. Mickiewicza 3, 31-120 Kraków, Poland; e-mail: agata.krzywdzinska@uj.edu.pl 
genre formula of the programme. NATO, in the assessment of selected $\mathrm{TV}$ programmes, is clearly viewed as an aggressive organization, encroaching closer on the borders of Russia.

\section{ARTICLE INFO}

Article history

Received: 10.09.2019 Accepted: 24.09.2019

Keywords

NATO's image, Russian television, society, programmes, content analysis

\section{BACKG ROUND}

The content analysis of the NATO's image on channel Russia-1 will provide answers to specific research questions as to the kind of information about North Atlantic Alliance activities that is transmitted to the viewers of Russian public state television.

Why is television the tested medium here? For many Russians it still constitutes the main source of information. For as foreign researchers noticed many years ago, television is the main multi-medium of the twentieth century.

"Television is a centralized system of storytelling. Its drama, commercials, news, and other programs bring a relatively coherent world of common images and messages into every viewing home. People are now born into the symbolic environment of television and live with its repetitive lessons throughout life (...)" ${ }^{1}$

As important as television itself is to define what an analytical programme and a talk show are. Polish media expert W. Godzic underlines that the study of television genres is actually a study of culture and the society that create this culture. ${ }^{2}$ It is therefore necessary to show the Russian academic point on television genres. Russian researcher L. Fiedotowa thinks that the Russian analytical programmes have already entered the mature phase which is closely related to the development of Russian public television:

${ }^{1}$ G. Gerbner, L. Gross, M. Morgan, N. Signorielli, Charting the Mainstream: Television's Contributions to Political Orientations, "Jounal of Communication", 1982, pp. 100-127, https://doi.org/10.1111/j.1460-2466.1982.tb00500.x

${ }^{2}$ W. Godzic, Telewizja - najważniejsze medium XX wieku, [in:] Media audiowizualne. Podręcznik akademicki, Warszawa 2010, p. 77. 
“(...) The modern stage of the evolution of television (1996-2006) is determined by the development of information and analytical programs as a mature type that has a number of typological features, because "the established domestic television market is gradually becoming the main subject determining the content of the television space in Russia «". ${ }^{3}$

Political and social talk shows are also well-known types of programmes on Russian television, mainly thanks to well-known hosts and the attractive formula of the programme. Guests invited to the studio talk about current topics in politics and presenters dynamize the programme with many questions and video journalistic materials.

Later in the article, analytical programmes and talk shows on channel Russia-1 will be described in detail.

\section{Methods}

The method used to study television programmes is content analysis. The research questions relating to the analysis of media content are: what kind of information about the North Atlantic Alliance is being passed on to the viewers of Russian public state television? What do they learn about NATO activity and what does this information bring to their knowledge? How do Russians evaluate the NATO activities in Europe and how does the Russian army and its technological capabilities appear within a comparative perspective? The qualitative analysis of the programmes was limited to several programmes broadcast from March and early April on the eve of the 70th anniversary of the organization and during the first week of April 2019. The probable research hypothesis is that one may expect a completely different media narration about the activities of this military organization than that existing within the Polish or the English speaking media.

\section{Selected programmes on channel Russia-1}

It is necessary to explain why the subject of the analysis is the channel Russia-1 and its programmes. Russia- 1 is a competitor of the television station Channel One Russia. Viewership of both channels is always the highest in viewership rankings but Channel One Russia has a much longer broadcast time. The channel Russia-1 began broadcasting on 13 May 1991 at 17:00 under the name Russian Television (RTR Channel) with the news

${ }^{3}$ L.N. Fedotova, Analiz soderzhanija sociologicheskij metod izuchenija sredstv massovoj kommunikacii, Moskva 2001, p. 49. 
programme Vesti. From 1 January 2010 by the decision of President Dmitry Medvedev, the channel changed its name to Russia-1 (Russian: Poсcия-1). The station's schedule includes news and current affairs programmes, analitycal programmes, including popular talk show programmes. ${ }^{4}$

It is also necessary to remember that these programmes are financed from the Russian state budget. Russian government control over television includes stations such as Russia-1. The first analyzed programme is called 60 minutes (Russian: 60 минуm). It is a recipient of a famous television reward TEFI in "Political and Social Prime-time Talk-shows" category (2017). The programme presenters, Olga Skabeyeva and Yevgeny Popov (in private life - a married couple), received the TEFI award in the category "Presenters of Political and Social Prime-time Talk shows" (2017). The programme has a daytime and evening edition.

\section{Release of 60 MinUtes Programme of 11 March 2019}

On 11 March 2019 the programme was dedicated, among others issues, to a discussion about the film The Unthinkable (Swedish: Den blomstertid nu kommer), a Swedish production of 2018. The introductory argument to the topic was how the film depicted Sweden being attacked by Russia. Evgeny Popov ironically mocked the subject of the film, which, in his opinion, is a fantasy: "Our great country is invading Sweden. Russian Spetsnaz is shooting at society. The power structure is blown up. And, attention! through the rain an unknown substance is sprayed, most likely novichok. We don't know. Let's watch the fragment". ${ }^{5}$

After broadcasting a fragment of the film, the studio discussion focused on the phenomenon of Russophobia in Sweden and on NATO activity. The film shows the growing tension in Swedish-Russian relations. The journalist was curious why the average Swede is brought up to be a Russophobe. The first and clearest voice in that discussion was raised by Igor Korotchenko, editor-in-chief of the military-political monthly "National Defense" and a member of the Social Council at the Ministry of Defence of the Russian Federation, director of the World Arms Trade Analysis Center. Here is a fragment of his statement:

\footnotetext{
${ }^{4}$ Television website: Telekanal Rossiya, https://russia.tv/

${ }^{5} 60$ minut ot 11.03.2019 [video], “Youtube.com”, 11.03.2019, https://www.youtube.com/ watch?v=asdORZD4lLU
} 
Sweden is a country with an arms industry. (...) Sweden has its famous Grippin fighter. Next, as far as infrastructure is concerned, there is an aerodrome in Sweden. Sweden's neutral status offends the eyes and the hearing of our American partners (...) this is not the first such film that is supposed to sway public opinion and prepare society to join NATO. Sweden is a happy country and people live there relatively comfortably. (...) Such films are intended to frighten Swedes. Showing Russia as a monster that is ready to use chemical and biological weapons, to switch off their memory. If you are afraid of Russia, you will vote for those politicians who want Sweden's integration with NATO. (...) The Poltava battle syndrome is within Swedish society. ${ }^{6}$

This statement clearly shows that Russians are very negative in their references to NATO enlargement. Building the image of Russia and arousing fear has a negative effect on Russian-Swedish relations, not only social but also political. Therefore, the programme was an attempt to reinterpret the film in its relations to Russia: the journalists and invited guests were explaining the reasons and tried to influence the thinking of the Russian viewers of the programme as to why specific topics are exposed and whether it has a chance of becoming popular. It seems that the most important factor for Russians is the scale of the film's impact. This is a blockbuster movie encroaching on the public consciousness, while the image of Sweden being attacked by Russia is encoded in the minds of Swedish society. Therefore the film The Unthinkable was important enough to become the subject of a discussion on a popular political and social talk show.

\section{60 MiNUTES RELEASE OF 4 April 2019}

The next edition of the programme expands the viewers' knowledge of NATO's activities over the past few decades along with an evaluation of Russian political and military activities. The second half of the programme begins with an introduction to the speech given on 3 April 2019 before Congress to mark the 70th anniversary of the Alliance. It was an assessment made by a Norwegian politician and NATO Secretary General Jens Stoltenberg. The studio presenters, Yevgeny Popov and Olga Skabeyeva, commented ironically on Stoltenberg's speech in Washington, describing the Secretary General as a "comrade" (as in Soviet times). Skabeyeva was particularly iron-

\footnotetext{
${ }^{6}$ Ibidem.
} 
ical about NATO's long-term activity: "If it had not been for NATO, the world would not have been saved from Hitler, Stalin and ISIS" ${ }^{7}$ her remark being a short introduction to the Secretary General's speech in Congress.

Jens Stoltenberg said: "And we will need to continue to deal with a more assertive Russia. In 2014, Russia illegally annexed Crimea. The first time in Europe that one country had taken part of another by force since World War Two. We see a pattern of Russian behaviour. Including a massive military build-up from the Arctic to the Mediterranean and from the Black Sea to the Baltic. (...) Hitler could not have been stopped with peaceful protest. Stalin could not have been deterred with words. ISIS could not have been defeated with dialogue (...). ${ }^{8}$

The speech was summed up as being a nightmare by the journalists present. The first comment on this was made by Sergei Markov, general director of the Institute of Political Sciences. He said that NATO was needed to keep Europe under US control, to restrict Germany so that the country would not be self-sufficient and to keep Russia away from the organization. He referred to NATO member countries as satellites. In his opinion NATO is a "coercion system of support for aggressive American actions". ${ }^{9}$ What he liked least was that NATO wants to expand its activity to other countries such as Brazil, Japan, Australia, or South Korea to create a global alliance.

The second part of the discussion was connected with Turkey that has bought the Russian S-400 missile defence system. Turkey is a NATO member, but Turkey has also been establishing closer links with Russia. Programme viewers saw the statement of the US vice-president Mike Pence, who called the purchase "a huge threat to NATO". ${ }^{10}$ The next person to comment on the purchase was Turkish minister of foreign affairs, Mevlüt Çavuşoğlu. He said that Turkey was an independent country and wanted to have a good relationship with its neighbours, and no one would decide with whom Turkey want to have good relations. "And it happened with Ukraine and look what happened". ${ }^{11}$ In a commentary to this statement,

\footnotetext{
${ }^{7} 60$ minut po gorjachim sledam ot 04.04.2019 [video], "Youtube.com", 4.04.2019, https://www.youtube.com/watch?v=euzfoTm3nd0 [37:11].

${ }^{8}$ Ibidem [36:54].

${ }^{9}$ Ibidem [39:54]; Oficial transcription: NATO: good for Europe and good for America, "North Atlantic Treaty Organization", 3.04.2019, https:/www.nato.int/cps/en/natohq/ opinions_165210.htm?selectedLocale=en

${ }^{10}$ Ibidem [44:56].

${ }^{11}$ Ibidem [45:35].
} 
a Ukrainian politician with pro-Russian views, Vadim Kolesnichenko said that this purchase was dictated by politics because "Erdogan is afraid of US aggression". ${ }^{12}$ The journalist Popov exclaimed with laughter: "The Turks want to defend NATO's borders with our equipment! Is it normal?!!"13

This part of the programme shows that Russian journalists have a clearly negative opinion of NATO. Guests invited to the studio express very similar opinions and any comment opposing this vision is loudly protested. The programme reflects Kremlin policy and journalists are not interested in any other point of view than the official Russian one.

\section{Other Russian programmes devoted to NATO}

Another very popular programme on Russian TV which analyzed NATO's activity is Nerws of the Week (Russian: Beсти недели, transcr. Vesti nedeli). The programme is headed by a well-known and charismatic presenter Dmitry Kiselyov, a subject of EU sanctions (as the only Russian journalist amongst those blacklisted). Vesti nedeli is a weekly information-analytical programme transmitted on Sunday at 8:00. Dmitry Kiselyov was nominated in 2014 for the previously mentioned TEFI award in the category of "Leading Information Programmes". In October 2017,TEFI award jury considered Vesti Nedeli the best information-analytical programme on air. In other surveys showing its viewer ratings in 2017 and 2018, the programme was chosen as the best within the group of analytical programmes. ${ }^{14}$

This time (07.04.2019) the viewers of the programme Vesti... were given a different introduction to information on NATO. At the beginning of the programme, Dmitry Kiselyov tried to assess 70 years of NATO history and activity. "How to evaluate the result?" asks Dmitry Kiselyov. "In NATO they say that this is the most effective alliance in the history of humanity, and in my opinion it is the least effective alliance that you can imagine. Where in this case is the evaluation criteria? The NATO bloc should be assessed according to the law they created themselves". ${ }^{15}$

The next thing the journalist pointed out was the words of an American politician Kay Bailey Hutchison, a former US senator from the Republi-

${ }^{12}$ Ibidem [51:07].

${ }^{13}$ Ibidem [50:30].

${ }^{14}$ Kak chasto i zachem ljudi smotrjat televizor. Kakie peredachi interesujut ljudej? Kak ocenivaetsja kachestvo sovremennogo televidenija?, https://fom.ru/SMI-i-internet/14029

${ }^{15}$ Vesti nedeli s Dmitriem Kiselerym ot 07.04.19 [video], "Youtube.com", 7.04.2019, https:/www.youtube.com/watch?v=aT-m5VGZt4E [01:07:22]. 
can Party, who had said that the North Atlantic Alliance was defending Europe and North America from Russian aggression. The journalist said he doubted that NATO had really defended any country over the past 70 years. The NATO budget is a trillion dollars per year with this being twenty times larger than Russia's military budget. For Kiselyov, NATO is a machine for pumping money into buying American weapons. He explained to viewers that Russia has its own borders and own law and it is incomprehensible why people blame Russia for moving closer to NATO borders. ${ }^{16}$ Programme viewers also saw a report from the conference in Washington which took place on 3-4 April 2019 to mark the seventieth anniversary of the Alliance. An accredited correspondent of Vesti Nedeli was there but none of the participants from Croatia and the Czech Republic wanted to give Russian TV an interview.

The next part of the analysis of NATO activity was the position and person of the Secretary General of the North Atlantic Pact. Kiselyov explained that the former Secretary General, Rassmusen, came to a meeting with president Putin with a microphone on his jacket and that made him appear stupid in public opinion. ${ }^{17}$ The current secretary, Stoltenberg, is also a specific person, he makes a "conceptual statement". ${ }^{18}$ What did he mean? This referred to the same part of Stoltenberg's speech in Washington about Hitler, Stalin and ISIS that was mentioned in the previous programme. Kiselyov summed it up that the organization was created in 1949 when the USSR was trying to pick itself up after the World War Two. Former allies like the United States, the United Kingdom and France quietly, behind the back of the USSR, created a military bloc against the Soviet Union. The journalist pointed out that one should remind this Secretary General of Norwegian origin that it had been Stalin who had pushed the Nazi occupiers out of Norway (Finnmark, to be precise) and some people still remembered this.

\section{Conclusions}

To understand Russian television, one needs to know its structure and form. Television creates its own order, directs the thinking of Russians and provides themes for discussion. The analyzed television programmes

\footnotetext{
${ }^{16}$ Ibidem [01:07:22].

${ }^{17}$ Ibidem [1:22:24].

${ }^{18}$ Ibidem [1:22:58].
} 
are socio-cultural constructs. They create a media reality that the Russian viewer assimilates (decodes) and that he or she considers to be reality.

Russian public state television channel Russia-1 presents a coherent narrative image of NATO regardless of the genre formula of the programme (political and social talk show, analytical programmes etc.). Basically, to put across a strong persuasive and manipulative message, the journalists of state television stations simultaneously use news and in-depth analysis with an extended broadcast time, a charismatic host, well-known public figures, a modern studio and infographics.

NATO, in the assessment of selected TV programmes, is clearly viewed as an aggressive organization, encroaching closer on the borders of Russia. Poland - referred to in one of the programmes as a satellite state of the Alliance - in the interpretation of Russian journalists wants to expand its influence in Ukraine and Belarus ("dominate colonially" - a statement from the programme 60 minutes of 11 March 2019). Russians think that NATO's ideology is becoming a national idea in Poland. This ideology is already being taught at schools. Poland is called a NATO training ground. According to Russians, Poles incorrectly assume that the greater the number of American soldiers in Poland, the smaller they will pay as a country - a member of the North Atlantic Pact. The Russian viewer is confirmed that Poland pays a very high financial price for being an ally of the USA. Television Russia-1 selects topics related to Poland and is limited to: intensive cooperation with NATO, "selective" memory of Poles, or rather its lack at the end and participation of the Russians in the liberation of Poland from German occupation during World War II. This builds a polarized picture of Poland: on the one hand uncritically adopting US principles, on the other strongly conflicting with Russia.

Demonizing the image of NATO is achieved through the use of such tactics as information selection, news agenda, the irony of the programme presenters, in order to reassure viewers that Russia is militarily strong and that there is no point to fear the Alliance.

Journalists in these programmes create a clear image of NATO, one visibly polarized: We: Russians - They: the Alliance. Therefore, the journalistic message about NATO is long-lasting and repetitive, which authenticates the message and ensures it is remembered. In this regard, analytical programmes have a great advantage over news information, which does not hold the viewer's attention for a long time: analysis allows for an interpretation of NATO activity and focuses thinking about the Alliance. From 
this perspective, political and social talk show programmes are the most effective and have the strongest influence on viewers.

\section{REFERENCES}

1. Fedotova L.N, Analiz soderzhanija sociologicheskij metod izuchenija sredstv massovoj kommunikacii, Moskva 2001.

2. Gerbner G. , Gross L., Morgan M., Signorielli N., Charting the Mainstream: Television's Contributions to Political Orientations, "Jounal of Communication”, 1982, pp. 100-127, https:// doi.org/10.1111/j.1460-2466.1982.tb00500.x

3. Godzic W., Telewizja - najważniejsze medium XX wieku, [in:] Media audiowizualne. Podręcznik akademicki, Warszawa 2010.

4. Kak chasto $i$ zachem ljudi smotrjat televizor. Kakie peredachi interesujut ljudej? Kak ocenivaetsja kachestvo sovremennogo televidenija?, https://fom.ru/SMI-i-internet/14029

5. NATO: good for Europe and good for America, "North Atlantic Treaty Organization", 3.04.2019, https://www.nato.int/cps/en/natohq/opinions_165210.htm?selectedLocale=en

6. Telekanal Rossiya, https://russia.tv/

7. Vesti nedeli s Dmitriem Kiselerym ot 07.04.19 [video], "Youtube.com", 7.04.2019, https://www.youtube.com/watch?v=aT-m5VGZt4E

8. 60 minut ot 11.03.2019 [video], "Youtube.com", 11.03.2019, https://www.youtube.com/watch?v=asdORZD41LU

9. 60 minut po gorjachim sledam ot 04.04.2019 [video], "Youtube.com", 4.04.2019, https://www.youtube.com/watch?v=euzfoTm3nd0).

Cite this article as:

A. Krzywdzińska, The Image of NATO in Russian Television on the 70th Anniversary of the North Atlantic Pact, "Security Dimensions", 2019, no. 31, pp. 22-31, DOI 10.5604/01.3001.0013.8552.

Licence: This article is available in Open Access, under the terms of the Creative Commons License Attribution 4.0 International (CC BY 4.0; for details please see https://creativecommons. org/licenses/by/4.0/), which permits unrestricted use, distribution, and reproduction in any medium, provided that the author and source are properly credited. Copyright (c) 2019 University of Public and Individual Security "Apeiron" in Cracow 